Bożena Sidor-Piekarska

Institute of Special Pedagogy

The John Paul II Catholic University of Lublin

\title{
THE SPECIFICITY OF EDUCATIONAL INFLUENCES IN RELATION TO A CHILD WITH INTELLECTUAL DISABILITY IN THE PROCESS OF EARLY SUPPORT TO THE DEVELOPMENT
}

\section{Introduction}

Amongst the youngest children there are many those whose developmental vitality is stopped or either temporarily or constantly slowed down. Children with psychomotor delay and with an already diagnosed intellectual disability develop just as any other children do. The need arises, however, for the increased parents' as well as people's from the child's closest environment or psychotherapists' care and attention in order to form this development appropriately.

It is hard to single out exceptional aims in raising a child with intellectual disability because the objectives of raising every child are similar. The situation of children with developmental difficulties is specific, however, because the parents' and psychotherapists' attention is most often concentrated very much on the child's problems as well as on preventing the new difficulties to appear or on working on the ones which have already arisen. In the situation of raising a child with disability, a high probability of improper parents' attitudes appear e.g.: overprotecting a child, making exaggerated expectations the child has to meet, and sometimes being indifferent to the child or rejecting him. These improper attitudes of parents are closely correlated with it the way the parents look at their child. Whether they see him mainly through the prism of disability or if they try to accept him with all the attributes he has. Specialists play an important role in the education process because the child from the moment of diagnosing the difficulty participates in various kinds of therapy forms.

Children with developmental problems put more effort into their own development, similarly to the education environment which adapts its support to their individual needs. 
Upbringing is a long sequence of changes happening in the process of thorough development, in which teachers participate deliberately as well as different situations and conditions cooperate. The very child's aspiration to achieving a greater mental, moral and practical self-reliance is essential (Kunowski, 1998).

For every child the way to self-reliance in satisfying personal needs, taking responsibility for one's own behaviour, meeting other people's expectations is a difficult road to follow. It is particularly difficult in the situation of experiencing restrictions of one's own efficiency by the child (Brzezińska, 2009). The development of children with disabilities proceeds more slowly and can be characterised by a smaller number of successes. However, as parents and specialists emphasize, one should use all of the child's potential and create as many situations as possible favourable to his development (Sidor 2003). It is essential that the child should feel safely, have good quality relations with family and friends, have an ensured environment rich in stimuli and should participate in various social relations, closely related not only with the process of rehabilitation.

Raising a child with developmental problems, one should notice his need of the autonomy and give him the chances for developing that kind of behaviour types which will allow him to function on the possibly highest level of independence in the future.

Two sets of attributes are particularly important, the forming of which at children with disabilities becomes a foreground task. The first set of attributes concerns the child's attitude to himself. The second set concerns the child's attitude to others. The objectives mentioned above determine the directions of educational influences (Muszyńska, 1999).

\section{Intellectual Disability - Clarifying the Notion, Diagnosing}

The newest presentation of mental disability, included in the10th edition of "Mental Retardation. Definition. Classification and systems of supports" ${ }^{1}$ shows that it is such a type of disability which can be characterized by a substantial limitation both in a mental functioning and in adaptation behaviour, which manifests in cognitive, social and practical adaptation abilities and develops before the age of 18. Among cognitive abilities the following are included: intercommunication, the ability to read and the ability of self-control. Social abilities include: interpersonal functioning, responsibility, establishing friendships, acting according to principles, obeying the law, the ability of spending leisure time. On the other hand, practical adaptation abilities include activities necessary in daily existence,

${ }^{1}$ Mental Retardation. Definition. Classification and systems of supports Mental Retardation. Definition, Classification and Systems of Supports New York 2002, American Association on Mental Retardation (AAMR) 10 Edition. 
preparing meals, taking care of one's health, housekeeping, money management, professional skills, supporting the environment in safety.

In this definition the significance of the effective system of support which should refer to the difficulties mentioned in the definition is emphasized and should be adapted to individual and changing needs of people with intellectual disability.

The diagnosis about a given degree of intellectual disability can be made after a child is three years old. Up to the third year of age, in the situation of a child's developmental difficulties, psychomotor development delay is most often stated. The possibility of diagnosing the intellectual disability early concerns mainly people with deeper deficiencies. A lot of cases of the intellectual disability, particularly that of a slight degree, is not recognised till school-age (Kirenko, Parchomiuk, 2008, p. 42). One should emphasize, that as soon as the psychomotor delay appears, when there is still no diagnosis of the intellectual disability, work with the child and his parents is necessary.

Action within a range of early work with the child and the family should be undertaken both in the situation of deep as well as slight difficulties.

Unfortunately children with a lighter degree of intellectual disability are diagnosed when the competent institution they are going to fulfil the school duty is being chosen for them. Communications about the difficulties a child has often appear only in the situations connected with choosing the school for the child.

In the situation of deep deficiencies, after making a preliminary diagnosis about the child's psychomotor delay, parents start looking for help on their own. In the beginning, help is most often correlated with the somatic condition of the child, next with the motor streamlining but then with the action of such specialists as a psychologist, pedagogue, speech therapist.

\section{The Characteristics of the Process of Early Help to the Child with Developmental Problems}

Assistance to the development is one of the many forms of help which people give to others mainly in everyday life situations. Within the scope of the assistance one can distinguish action taken by professionals as well as natural action taken by people towards others, usually when a certain situation is assessed as too difficult for a given person. Parents, siblings, teachers are usually such people who help him in the natural way. Talking further about help, we can mention action directed to a given person or the group as well as action directed to the life environment, the context of functioning (Brzezińska, 2006, p. 684).

In the course of providing the support, one should be guided by subjectivity. In all actions correlated with assistance to the development one should remember that (Kwiatkowska, 2006 a, p. 7): 
- the supported person is first and foremost a human and only then the person with disability,

- as a human he has an inalienable right to take independent decisions,

- accompanying the development of the disabled person one should not only follow this right but also learn to use it.

Assistance to the development according to I. Obuchowska (2003, p. 7) is an interdisciplinary and collective notion, it is a process of the professional influence on children (to people being in the so-called developmental age) in the purpose of strengthening or arousing specific functions of the mental and social development. By the notion ,collective” I. Obuchowska understands the multitude and diversity of influences taken as part of early assistance. It cannot be a single activity but a complex process. Along with the child's development, interaction between the supported and the supporting person gains a greater meaning in this process. The terms „,support” and ,assistance” are used interchangeably and mean „,being” with the other person and overcoming the difficulties in solving all sorts of practical problems with her.

B. Kaja (2002, p. 260) characterises assistance to the development in the following manner:

- assistance to the development can be described as a special kind of interaction of a human with a human;

- the influence exerted in addition is a professional influence;

- it is rational influence;

- offering values is an essential condition of assistance;

- assistance has a subjective character;

- ,assistance to the development is about the quality of life as well as the quality of the world".

Taking action in favour of the child, the following factors should be in the focus of attention of the supporting people (Obuchowska 2003, p. 13):

- the bond: child - parents (deepening the bond and basing it on sound principles are a task);

- identity of the child (teaching the child self-acceptance is a task),

- self-esteem of the child (strengthening it is a task),

- empathy of the child (developing it is a task).

In case of children with the intellectual disability early assistance to the development should contribute to minimizing the degree of the disability and to emphasizing the developmental potential so that in the future they are independent up to their capabilities, were able to communicate with environment, to use the available forms of communication appropriate for them. On the other hand, for the parents it is a chance to understand children's needs, becoming stronger in parental competence and accepting the difficult situation which raising a child with disability is so that the family can realize various practical objectives (KastoryBronowska, Pakuła 2004). 
Even in case of people with the deeper degree of intellectual disability it is possible to assist the development with positive effects. It is made through using various forms of communicating, sensory stimulation, forming self-reliance in terms of everyday care activities (Olechnowicz, 1999, p. 20; Batko, 2002; Wiśniewska 2008, p. 14).

In the work with people with slight intellectual disability I. Obuchowska (1999, p. 241-250) emphasises the significance of:

- home environment for forming one's personality;

- the role of one's own activity while gaining knowledge and experience;

- learning by gaining experience while participating in various social situations;

- acting subjectively, enabling the person with developmental problems to make his own choices, taking even the simplest decisions.

Helping a young child requires knowledge about the mechanisms of the development and about the ways of supporting it as well as adapting methods, forms and measures of work to the child's needs and his dominating activity. One should not identify early assistance to the development of young children endangered with disability with special education of a kind (Piszczek, 2002, 2007, p. 154). The process of supporting the child's development is not practising individual functions. Every influence of the adult affects comprehensive functioning of the child, also that of personality. The conducted classes should be closely connected with the activities typical for children as well as his interests and every activity should be connected with others (Piszczek, 2007, p. 150; Cieszyn, Korendo 2008). The therapy should not be a set of exercises separated from the entirety of the education action (Kościelska 1998, p. 132).

Early assistance to the development is the time when playing is an activity typical for every child, which should be taken into consideration in the course of organising therapeutic classes. The teacher is an ,intermediary” between the child and the world of objects and people surrounding him rather than the person communicating ready messages to the child in a formalised way (Brzezińska 2007, Piszczek 2006). Playing with a disabled child can be distinguished by certain specificity. During these games or learning, it is important to wait for the child's response. Impatience, constant demonstration of what the child should do without giving him the chance of trying and experimenting is not a due conduct. Hurry and too fast repetition can stop the child from making an effort. He can then fall into the state of only passive reception and remain only a non-active observer (Fannie 1994). The child with intellectual disability usually needs „children's” games for a longer time (Olechnowicz 1997). He puts an effort, a real work into playing. Therefore a teacher who is the child's guide plays such an important role. The teacher should plan the course of the following activities starting from the simplest ones for the child and finishing on the ones which provide a challenge for the child. The child with intellectual disability loses his chance for knowledge 
acquisition by inappropriate dealing with him. Sometimes one word which is too difficult or too rapid pace or one insufficiently established ability waste all the educational effort. In case of a child without developmental difficulties, the mistake in educational conduct has relatively little consequences because a young person is capable of self-aggrandizement. In case of the child who has trouble with every intellectual effort the smallest disruption in grading the difficulties can have serious consequences (Brauner, Brauner 1995).

Another important sphere of supporting the development of children with developmental difficulties are the methods of working with the child. Not having knowledge about the ways of working with the child, parents feel lost amongst various methods of therapy. They search for the one which would the most appropriate, the best. It is very often carried out by means of experiments and sacrifices. In the process of rehabilitation of the child, sometimes the very specialists forget that methods have secondary significance in comparison with the contact with the child. And the very quality of contacts of the child with his parents and psychotherapists is the ground for him to achieve success. Treating the methods of therapy as the most important factor in the process of rehabilitation, the child becomes the object of the rehabilitation action and not its subject. Parents should also be sensitised to the fact that their own child is the subject of the rehabilitation action. It is important therefore to pay attention to the child's frame of mind, his functional capacity or how active he is while applying various work methods. Accordingly, sometimes the number of various classes should be reduced because of the strong tiredness of the child.

Only if the need for the emotional contact is satisfied, the child can display diverse activity, master new skills and abilities (Twardowski, 1999, p. 596).

The greatest threat for the child's development can be found in the wrong relations with the social environment and the greatest hope for improving the development is connected with the improvement in these relations (Kościelska, 2007 , p. 630). The intellectually disabled persons are very often exposed to isolation (Bakiera, Stelter 2010 p. 143) and after all the effects of the action taken in the range of early assistance to the development to a large extent depend on the opportunity the people with intellectual disability have to stay in various environments as well as on the openness of these circles for their participation in social life. While making consecutive attempts in the forms of therapy, it is essential not to forget that in the child's development other people play the greatest role - initially the parents and with time the extended family and peers as well as particularly important adults such as teachers, psychotherapists, etc.

As a rule, the non-disabled people function in the roles which enable them to gain a lot of experience in terms of relations. They participate in symmetrical as well as asymmetrical relations. However, people with intellectual disability often function only in the situation of subordination. It often happens that they know themselves only in the role of a charge. They are the weaker people who are 
necessary to look after and who need help and support. They see themselves as dependent people. Such experience may lead to adopting a passive, welfare state mentality (Przebinda, Zawadzka 2002, 24-25 p.; Walczak, 2006 p. 90).

Distinct diversification of the circles in which the child stays makes him become more independent. He starts establishing various relations and fulfilling himself in various roles (Bakiera, Stelter 2010).

\section{Specificity of Educational Influences in Reference to the Child with Intellectual Disability}

In what way the disability is going to affect the child's development depends in the greatest extent on adults' behaviour, above all on that of both parents. Their behaviour types, communications, displayed emotions decide whether the disability will be the basic feature in their child's characteristics. If parents focus their energy on the constant "making up for shortages" rather than on supporting the child's development taking him as he is, then unfortunately it is probable that the disability will be the main attribute in the child's characteristics. It will be a more and more determining factor in what the child thinks about himself, how he sees his capabilities, how well he does in comparison to others (Ohme 2009). While raising a child with disability it is important what is in the centre of awareness of the parents and carers - the child or his disability. Whether they want - considering developmental difficulties of the child - to provide him with the best possible conditions for the development or whether they concentrate on the disability itself and the direct effects it has on the child's functioning (Brzezińska 2009, p. 16,17).

The most beneficial effect on the child with disability, also the one with intellectual disability, has "a simple accompanying and supporting him instead of special care" (Kwiatkowska 2006, Resler- May 2010). Thanks to encouraging their development, people with intellectual disability should be able to understand the world surrounding them better and better, should be understood by their environment, experience satisfaction and self-esteem every day (even while making simple initiatives) so that they can get to like themselves (Kwiatkowska 2006).

Optimal educational environment is the situation when adults set the requirements for the child including the restrictions correlated with his developmental problems and at the same time they use and enhance his competence and the assistance provided can be defined as "minimally necessary" and "withdrawing" help. Such environment encourages the formation of self-confidence and the sense of subjectivity i.e. the feeling that the child can have an influence on everything that happens around him and belief that other people value his opinion. Such upbringing can be described as subjective, open for the child's needs and at the same time preparing him for satisfying his personal needs in an autonomous way 
and respecting norms and social rules. Characteristic for subjective upbringing are high requirements, responsibilities appropriate to the situation and the child's capabilities as well as support appropriate to the child's needs (Brzezińska 2009).

Rigorous and overprotective upbringing as well as neglecting the child affect his development in a negative way (Brzezińska 2009, p. 43-47). Here the measures of upbringing are closely correlated with improper parents' attitudes: overdemanding attitude, overprotective attitude, indifferent attitude and the one rejecting the child (cf. Ziemska 1986, Kielin 2003). In the situation of the rigorous upbringing, parents have excessive demands towards the child, which causes great stress in children. Parents give the child too little support in relation to his needs. In overprotective upbringing, few demands make the child burdened too little. There is too much support in relation to the child's needs. In the situation of neglecting the child, low requirements but strong burdening with numerous duties appear. The support is insufficient in relation to the child's needs (Brzezińska 2009).

The exaggerated care even with good intentions of parents or grandparents limits the process of reaching independence and forming autonomy by the child. It disturbs the process of forming one's identity, i.e. the sense of physical and mental difference from other people and at the same time the sense of belonging to sex or age group (Brzezińska, 2006). We deal with limiting the child's self-reliance not when the other person helps him to accomplish the task but when the other person makes decisions and helps the child or instructs and corrects him, shows things, carries out the tasks instead of the child but also when the person does not provide the child with appropriate support so that he believes in his own success (Brzezińska 2009, p. 47,48).

It should be emphasized that not only education and streamlining should be the aim of early assistance to the development but such a way of raising the child so that he would be a person as independent, happy and making decisions within his capabilities as possible. So that he could find fulfilment in social and emotional spheres.

Sometimes the paradox of the entire life of people with intellectual disability consists in them spending life on that kind of learning which is based on the intellect. Work schedules which are based only on the specificity of intellectual functioning and focusing on the weakest point of the person cause that people with intellectual disability are bound to make continuous failures. And the thing is that apart from the lowered intellectual functioning they have an emotional sphere, their own temperament and potential to use and work on. If the entire attention of the environment is focused on their weakest point then their living "becomes a torment". It should not be so that the living of this group of people is concentrated only on learning and constant educating. The intellectually non-disabled people study in order to live better, however, the people with intellectual disability live in order to study (Kwiatkowska 2006 c, p.12-13). 
While raising a child with disability one should emphasize the meaning of action for forming the child's autonomous behaviour types.

The work on assistance to the development of autonomous behaviour should start as early as possible and should be treated as the integral aim of all educational and therapeutic influences (Batko, 2002 p. 11). Raising a young child with intellectual disability to the autonomy requires taking many factors into account, among others appointing rehabilitation aims favourable to its formation.

The sign of respecting the child's autonomy is when the adult grants the following :

- the right to the free choice of the task and the kind of activity;

- the right to free determining the ways of solving a problem;

- the right to free expressing their own assessment of what is happening around them, assessment of themselves and the effects of their work and assessment with reference to the adult.

The closed style of contacting the child when the source of children's activity is beyond children encourages limiting the autonomy of the child. The mother, father, psychotherapist or other adult becomes the person who always knows better, can do everything, nothing is surprising for him. The child takes the role of the obedient and "good" one, who carries out instructions or on the other hand, becomes rude focusing others' attention to his individual needs (Brzezińska 2009, p. 32)

The respect of the rights favourable for forming autonomous behaviour contributes to forming the responsibility for the action taken by oneself. However, this sense develops when the adult takes care of forming the firm base earlier at the child i.e.: the sense of freedom of choice, the sense of exerting influence on what is happening around, the sense of having control over events (Brzezińska, 2009, p. 29.30).

\section{The Directions of Educational Influences with Reference to the Child with Intellectual Disability}

In the process of upbringing, one should develop particular attributes of the child. Forming these qualities is at the same time accomplishing educational purposes correlated with forming the child's autonomy (Muszyńska 1999; Jaszczuk, Ziątek, 2000, Batko 2002). Two sets of attributes are important, the forming of which at children with disabilities becomes a foreground task. The first set of attributes concerns the child's attitude to himself. Within this set forming selfreliance, emotional resistance, optimism, self-approval are particularly important. The other set concerns the relationship of the child to others. Here the formation of socializing, communicativeness, public spirit and the ability of cooperation and assertiveness are particularly important. The objectives mentioned above determine the directions of educational influences (Muszyńska 1999). 
Self-reliance is the first discussed objective. One should treat this area as the foundation it is possible to build more complex autonomous behaviour on. The person becomes independent in his choices and judgments in a considerably easier way if he does not depend on other people in meeting the essential needs (Batko 2002, p. 11).

Within the scope of self-reliance we can distinguish two aspects. The first one refers to the level of performing various activities e.g.: in the range of getting dressed, eating, self-reliance in the toilet, performing simple everyday activities at home and outside it, moving around without the other person's control, doing homework, establishing social contacts, money management (Muszyńska, 1999, p. 113). The other category is controlling one's own action. For developing selfreliance forming motivation for independent task accomplishment is essential. Creating the opportunity to take up even minor decisions is important. Working with the child, it is important to create and use all chances for making choices from available objects, places and people the child will want to cooperate with. Limiting self-reliance in the scope of everyday activities causes hindering the process of cognitive and social development (Muszyńska, 1999, p. 113, Batko 2002). Developing the ability to make choices should start as early as possible, the very moment the child is able to express his agreement or refusal (Batko 2002, p. 18). Saying "no" has a considerable value in the process of development, it proves the aspiration to self-determination and having one's own preferences.

In the process of forming autonomous behaviour, emotional resistance is another important objective. It reveals in the so-called difficult situations and manifests itself with the ability and readiness to overcome them. These difficulties can have various forms: threat, disruption, deprivation, surcharge, pain (Muszyńska, 1999, p. 113).

It is of great significance for forming the emotional resistance of the child how the parents react to the difficulties of the child's everyday life, what their attitudes towards the child are and what relationships in the family are (Muszyńska, 1999, p. 113). The person with disability must learn how to deal with difficult, frustrating and painful situations which appear in his life so as not to become depressed at that time, not to lose motivation to being active and overcoming the difficulties. Educational influences should aim at forming the emotional resistance and optimistic attitude towards the world (Batko 2002, p. 22; Jaszczuk, Ziątek 2006, 26).

A quality which can co-occur with emotional resistance is optimism. According to H. Muszyńska (cf. Muszyńska 1999, p. 126). It consists in the tendency of a man to include in one's predictions everything in the categories which are in accordance with one's own wishes as well as in the tendency to discern positive aspects in everything around them, which gives the reason for joy.

The way family members behave in case of failures may constitute for the child a pattern starting the process of modelling and to a large extent influence the 
perception of reality and the vision of the future. In case of families raising a disabled child we often deal with an oppressive atmosphere of pessimism connected mainly with the situation of the child. This atmosphere can arise from objective reasons, e.g. insufficient medical care or lack of different forms of therapy. One can and one should develop the atmosphere of optimism on account of its significance for the child's development (Muszyńska 1999, p. 130).

Another important aim in the process of forming autonomous behaviour types is self-approval.

Self-approval is often identified with positive self-assessment, the self-assessment is an important factor of self-approval (cf. Muszyńska 1999, p. 130), which reflects the sense of competence in various areas. It also includes the sense of effectiveness of one's own action, which is shaped due to information from other people. On this base self-esteem and the image of oneself are built (Przebinda, Zawadzka, 2002).

People with intellectual disability are characterised by the weak knowledge of their own feelings, thoughts and motives. Their self-assessment is unrealistic, they are sometimes uncritical in relationship to their own capabilities or on the contrary, they do not believe in their abilities, deprecate the value of themselves, which may cause depression and impairing motivation to act (Batko 2002, p. 20). On one hand, people with intellectual disability are not able to cope with all the tasks and they experience failures, which in consequence leads to the negative self-assessment. On the other hand, such attributes as to week criticism, being prone to suggestions pose the danger of inflated self-assessment (Mitrut, 1998).

The other group of qualities important in forming the autonomy of the child with intellectual disability are those connected with forming one's opinion about others. The person develops, satisfies his needs, realises himself in the social environment which can either support or limit the development of the person. The chances for autonomous functioning are to a large extent dependent on communicative and social abilities of a given person (Batko 2002, p. 15.)

One of the qualities connected with forming one's opinion about others is socializing. The ability to follow social norms and the development of empathy are connected with the child's opportunity to be put in different situations. The child's participation in various social situations e.g. in relations with siblings or children at kindergarten enables the child to know social norms and their gradual acquisition through constant training.

The difficulties with forming the skills of social functioning at the child with disability can result from the child's personal qualities or (and) from the idiosyncrasies of the social environment e.g. attitudes of exaggerated protection, reluctance, hostility as well as curiosity or pity (Muszyńska 1999, p. 139).

A very important ability for every person with intellectual disability is finding the optimum level of balance between the aspiration to independence and the necessity to get the necessary help from others. 
Another feature connected with forming the opinion about others is communicativeness. In order to form the willingness of communicating with other people at children with difficulties, it is essential that the people who take care of the child were able to listen patiently to the messages he is able to communicate with the means accessible to him as well as not to ignore the messages (Batko 2002, p. 15). Learning to communicate can only take place by the contact of the child with other people. The greater diversity of these contacts is, the greater possibility of fast and effective learning of communication appears.

The basis for the functions of communication constitute:

- developing the ability to notice things;

- improving the ability of understanding, interpreting various types of information and enriching knowledge;

- speech development;

- aspiration to establishing social contacts (cf. Muszyńska 1999, p. 142).

In terms of public spirit and the ability to cooperate the next important aim which should be shaped while developing the child's autonomy, one of the most important means of teaching the child the desirable activity, is providing him with behaviour patterns. The child learns to help others, to comfort them and to respect other people's properties if in everyday life he has a chance to observe close people behaving in this way. The family but also important people from a more distant social background are most often such role models (Muszyńska 1999, p. 145).

The following factors do not favour public spirit and cooperation:

- improper attitudes in social environment;

- isolation from the environment of non-disabled people.

Egocentricity, aggressive behaviour, passivity and fear of people are the effect of these circumstances. The best way of counteracting it (a kind of prevention) is teaching the children proper behaviour types in various difficult situations rather than protecting children from them (Muszyńska 1999, p. 146).

Creating the situation of communicating in the class and cooperation between pupils are an important task of the teacher, achieved by provoking adequate situations e.g. by giving pupils the opportunity to play the role of a supporting and protective person rather than only that of the supported or protected one(Walczak 2006).

Among the discussed social features, assertiveness seems the most difficult Kwiatkowska 2006b, p. 16).

Assertiveness means self-confidence, concern about one's own rights and needs but at the same time having respect for emotions, rights and needs of others. Here are the rules of behaviour which are to teach the child basic assertive abilities:

- the ability to express anger or embarrassment;

- the ability to respond to criticism and attack,

- the ability to ask for what one's wants,

- the ability to accept refusal and rejection (cf. Muszyńska 1999, p. 146). 
Training assertive behaviour types should be conducted on the base of real everyday life situations, above all by showing respect to the people with disability, avoiding authoritarianism and dominance, establishing partner relations and obeying their rights. Modelling and imitating important people is especially significant here. In this way self-esteem and the feeling of dignity will become natural.

The person who feels worse than others does not give the right to assertiveness for himself and does not even realize that he has such a right. Unfortunately in the upbringing and teaching people with intellectual disability, teaching them the ,ingratiating good behaviour" dominates along with ,punishing” for negative emotions, executing simple orders while being instructed all the time (Kwiatkowska 2006 b, p. 17).

The desired assertive behaviour proves the acquisition of the ability to execute one's rights, to express both negative and positive emotions as well as to accept other people's emotions and opinions and to constitute one's rights. Expressing individual beliefs and opinions speaking on the broad forum are also meaningful (Walczak 2006, p. 90).

To sum up, one should emphasize the meaning of the process of raising children with intellectual. Disability. Very often parents, close and more distant environment of the child, psychotherapists concentrate on the process of rehabilitation, methods and forms of streamlining the child. Education and rehabilitation become an objective foreground task while those correlated with upbringing can be less important. It has many negative consequences particularly in forming the knowledge about oneself by the child and in his forming the relations with the environment.

The development of a person with intellectual disability largely depends on his individual capabilities of accumulating and organising experiences and his own activity in relations with environment. Supporting the development should be based on creating such situations which would allow to collect experience and knowledge, to develop social abilities including sensory functioning, interests and needs of the child (Brzezińska 2009, p. 16, Wiśniewska 2008, p. 14). One should be able to prepare the child for taking the initiative, to get his attention, interest, to acquire his participation. Relations between the child and his carer can be created in everything they can successfully do together (Brauner, Brauner 1995).

It is important to raise a child to the greatest possible autonomy because excessive concentration on the child, characterised by doing things for him, avoiding putting him in problem situations makes him helpless in life, demanding the direct, constant help (Marcinkowska of 2010 p. 208). Possibly the highest level of the autonomy of the child with intellectual disability should be reflected in the quality of his life and should give him the chance to function successfully in the open environment.

Key words: intellectual disability, child with intellectual disability, early assistance to the development, raising a child with intellectual disability 


\section{References}

Bakiera L., Stelter Ż. (2010). Wspomaganie rozwoju osób niepetnosprawnych intelektualnie. [In:] A. Brzezińska, R. Kaczan, K. Smoczyńska [Ed.]. Diagnoza potrzeb i modele pomocy dla osób z ograniczeniami sprawności, p.143- 162. Warszawa: Wydawnictwo Naukowe Scholar.

Batko E. (2002). Wspieranie rozwoju zachowań autonomicznych uczniów głębiej upośledzonych umystowo [In:] Przewodnik dla nauczycieli uczniów upośledzonych umystowo w stopniu znacznym i umiarkowanym, part II, p. 9-23. Warszawa: Centrum Metodyczne Pomocy Psychologiczno- Pedagogicznej.

Brauner A., Brauner. F. (1995). Postępowanie wychowawcze w upośledzeniu umysłowym. Warszawa: WSiP.

Brzezińska A. (2005). Jak skutecznie wspomagać rozwój [In:] A. Brzezińska A. [Ed.]. Psychologiczne portrety człowieka., Gdańsk: Gdańskie Wydawnictwo Naukowe.

Brzezińska A. (2006). Dzieciństwo i dorastanie: korzenie tożsamości osobistej i społecznej. [In:], A. Brzezińska A., Słomska J. [Ed.]. Edukacja regionalna. Warszawa: Wydawnictwo Naukowe PWN.

Brzezińska A. (2007). Społeczna psychologia rozwoju. Warszawa: Wydawnictwo Naukowe Scholar. Brzezińska A. (2009). Drogi dziecka ku samodzielności: między sprawnościa a niepetnosprawnościa, [In:] Brzezińska A., Ohme M., Resler- Maj A., Kaczan R., Wiliński M. [Ed.]. Droga do samodzielności - jak wspomagać rozwój dzieci młodzieży z ograniczeniami sprawności. Gdańsk.

Cieszyńska J., Korendo M. (2007). Wczesna interwencja terapeutyczna. Kraków: Wydawnictwo Edukacyjne.

Fannie, N. (1994). Domowa pielęgnacja małego dziecka z porażeniem mózgowym. Warszawa: Agencja Wydawnicza TOR.

Jaszczuk J. Ziątek K. (2006). Dziecko niepetnosprawne ruchowo na drodze do niezależności. Warszawa: Stowarzyszenie Spokojne Jutro.

Kaja B. (2002). Wspomaganie rozwoju - nauka czy tylko próba interdyscyplinarnego uporządkowania problemów? [In:] B. Kaja, [Eds.]: Wspomaganie rozwoju. Psychostymulacja i psychokorekcja. Bydgoszcz: Wydawnictwo Akademii Bydgoskiej. Tom IV.

Kastory- Bronowska M., Pakula Z. (2004). Model opieki nad dziećmi w wieku od 0 do 7 lat z zaburzeniami rozwoju psychoruchowego w Ośrodku Wczesnej Interwencji. [In:] Kmita G., Kaczmarek T. [Ed.]. Wczesna interwencja miejsce psychologa $w$ opiece nad mały dzieckiem i jego rodzina. Warszawa: Wydawnictwo Emu.

Kielin J. (2003). jak pracować z rodzicami dziecka upośledzonego. Gdańsk: Gdańskie Wydawnictwo Psychologiczne.

Kirenko J. Parchomiuk M. (2008). Edukacji rehabilitacja osób z upośledzeniem umysłowym. Lublin: Drukarnia i Wydawnictwo Akademickie WSSP.

Kunowski S. (1993). Podstawy Współczesnej Pedagogiki. Warszawa: Wydawnictwo salezjańskie.

Kwiatkowska M. (2006). Od autorów [In:] Jestem-rozważania o asertywności osób z niepetnosprawnościq intelektualna. Warszawa: Centrum Metodyczne Pomocy PsychologicznoPedagogicznej.

Kwiatkowska M. (2006b). Czy zechcemy słuchać [In:] Jestem-rozważania o asertywności osób z niepetnosprawnościa intelektualną. Warszawa: Centrum Metodyczne Pomocy PsychologicznoPedagogicznej.

Kwiatkowska M. (2006c). Zwyczajne towarzyszenie zamiast specjalnej troski. Warszawa: Centrum Metodyczne Pomocy Psychologiczno- Pedagogicznej.

Kościelska M. (2007). Psychologia kliniczna dziecka [In:] J. Strelau, [Ed.]. Psychologia. Gdańsk: Gdańskie Wydawnictwo Psychologiczne. 
Kościelska M. (1998). Trudne macierzyństwo. Warszawa: Wydawnictwa Szkolne i Pedagogiczne.

Marcinkowska B. (2010). Model pracy z uczniem z upośledzeniem umysłowym w stopniu umiarkowanym lub znacznym. [In:] Podniesienie efektywności ksztatcenia uczniów ze specjalnymi potrzebami edukacyjnymi. Materiaty dla nauczycieli. Warszawa: MEN.

Mental Retardation. Definition, Classification and Systems of Supports (2002). New York: American Association on Mental Retardation (AAMR) 10 Edition.

Mitrut A. (1998). Postawy wychowawcze rodziców samoocena i samoakceptacja $u$ ich dzieci uczęszczajacych do szkoły podstawowej dla lekko upośledzonych umystowo. [In:] Warszawa: Roczniki Pedagogiki Specjalnej, t. 8, p. 197-209.

Muszyńska E. (1999). Ogólne problemy wychowania w rodzinie dzieci niepelnosprawnych [In:] Obuchowska I. [Ed.]. Dziecko niepetnosprawne w rodzinie. Warszawa: WSiP.

Ohme M. (2009). Rodzina i dziecko z ograniczoną sprawnością w pierwszych latach życia, [In:] Brzezińska A., Ohme M., Resler- Maj A., Kaczan R., Wiliński M. [Ed.]. Droga do samodzielności - jak wspomagać rozwój dzieci młodzieży z ograniczeniami sprawności. Gdańsk.

Obuchowska I. (1999). Dzieci upośledzone umysłowo w stopniu lekkim. [In:] Obuchowska I. [Ed.]. Dziecko niepetnosprawne $w$ rodzinie. Warszawa: WSiP.

Obuchowska I. (2003). Wokół wspomagania rozwoju - poszukiwanie terminologicznej jasności. Rewalidacja, 2 (14), p. 4-13.

Olechnowicz, H. (1997). Dobre chwile z naszym dzieckiem. Warszawa: WSiP.

Olechnowicz H. (1999). Jaskiniowcy zagubieni w XXI wieku. Praca terapeutyczna z małymi dziećmi. Warszawa: WSiP.

Piszczek M. (2002). Wczesne wspomaganie rozwoju, part I, Rewalidacja, p. 5-11.

Piszczek M. (2006). Wczesne wspomaganie rozwoju-najczęściej popetniane błędy [In:]. Cytowska B. Winczura B. [Ed.]. Wczesna interwencja i wspomagania rozwoju małego dziecka. Kraków: Impuls.

Piszczek M. (2007). Diagnoza i wspomaganie rozwoju dziecka. Wybrane zagadnienia. Warszawa: Centrum Metodyczne Pomocy Psychologiczno- Pedagogicznej.

Przebinda W., Zawadzka M. (2002). Rozwój autonomii uczniów niepetnosprawnych ruchowo z upośledzeniem umysłowym [In:] Przewodnik dla nauczycieli uczniów upośledzonych umysłowo w stopniu znacznym i umiarkowanym, part II. Warszawa: Centrum Metodyczne Pomocy Psychologiczno- Pedagogicznej.

Resler-Maj A. (2009). Wspomaganie rozwoju dziecka z ograniczona sprawnościa wieku przedszkolnym [In:] Brzezińska A., Ohme M., Resler - Maj A., Kaczan R., Wiliński M. [Ed.]: Droga do samodzielności - jak wspomagać rozwój dzieci młodzieży z ograniczeniami sprawności. Gdańsk: GWP.

Sidor B. (2003). Wychowanie dziecka z niepetnoprawnościa umystowa a ujęcie procesu wychowawczego Stefana Kunowskiego. [In:] Nowak M., Ożóg T., Rynio A. [Ed]: W trosce o integralne wychowanie. Lublin: Wydawnictwo KUL.

Twardowski A. (1999). Pomoc rodzinom dzieci niepetnosprawnych, [In:] Obuchowska I., [Ed]. Dziecko niepetnosprawne w rodzinie. Warszawa: Wydawnictwa Szkolne i Pedagogiczne.

Walczak M. (2006). Towarzyszyć, wspierać czy ochraniać? [In:] Jestem- rozważania o asertywności osób z niepetnosprawnościa intelektualna. Warszawa: Centrum Metodyczne Pomocy Psychologiczno- Pedagogicznej.

Wiśniewska M. (2008) Wspomaganie rozwoju dziecka z niepetnosprawnościa intelektualna. Kraków: Impuls.

Ziemska M. (1986). (Ed.) Rodzina i dziecko. Warszawa: PWN. 